\title{
Efektifitas Pemanfaatan Fly Ash Batubara Sebagai Adsorben Dalam Menetralisir Air Asam Tambang Pada Settling Pond Penambangan Banko PT. Bukit Asam (Persero), Tbk
}

\author{
Alieftiyani Paramita Gobel, Edy Nursanto, Wawong Dwi Ratminah \\ Jurusan Teknik Pertambangan, Program Studi Magister Teknik Pertambangan \\ UPN "Veteran" Yogyakarta \\ Email : alieftiyanigobel@gmail.com
}

\begin{abstract}
ABSTRAK
Penanganan AAT yang banyak dilakukan di perusahaan tambang batubara dengan cara pemberian batu kapur masih kurang efektif karena pemberian batu kapur hanya untuk meningkatkan $\mathrm{pH}$ rendah menjadi $\mathrm{pH}$ netral, namun tidak dapat menurunkan kandungan logam Fe dan Mn. Berdasarkan hal tersebut, maka penulis melakukan penelitian di PT. Bukit Asam (Persero) Tbk. yang terletak di desa Tanjung Enim, Kecamatan Lawang Kidul, Kabupaten Muara Enim, Provinsi Sumatera Selatan untuk menganalisis efektifitas pemanfaataan fly ash sebagai adsorben dalam menetralisir AAT. Aplikasi penggunaan fly ash skala laboratorium dengan volume AAT $250 \mathrm{ml}$ dengan variasi massa fly ash 5,10 dan 12 gram dan kecepatan pengadukan 30 dan 45 rpm. Hasil pengujian menunjukkan bahwa adanya penambahan massa fly ash dan kecepatan pengadukan terjadi peningkatan $\mathrm{pH}$ dan penurunan konsentrasi logam $\mathrm{Fe}$ dan $\mathrm{Mn}$. Penyerapan logam Fe dan Mn oleh fly ash batubara dapat terjadi karena fly ash mengandung senyawa mineral utama yaitu kuarsa $\left(\mathrm{SiO}_{2}\right)$ dan mullite $\left(\mathrm{Al}_{6} \mathrm{Si}_{2} \mathrm{O}_{13}\right)$ yang berperan pada proses adsorpsi antara logam berat dengan adsorben fly ash dalam larutan mengandung air. Berdasarkan hasil analisis, efektifitas massa fly ash terhadap perubahan kadar $\mathrm{pH}$ rata-rata sebesar $63,11 \%$. Selanjutnya efektifitas massa fly ash terhadap perubahan konsentrasi logam Fe rata-rata sebesar 85,95\%, sedangkan efektifitas massa fly ash terhadap perubahan konsentrasi logam Mn rata-rata sebesar 81,77\%. Oleh karena itu, kapasitas adsorpsi logam Fe lebih besar daripada kapasitas adsorpsi logam Mn yaitu kapasitas adsorpsi logam Fe sebesar 4,938 mg/g sedangkan kapasitas adsorpsi logam Mn sebesar 4,296 mg/g mengikuti model adsorpsi isotherm Freundlich.
\end{abstract}

Kata Kunci: Fly Ash, Air Asam Tambang, Adsorben

\begin{abstract}
Handling of AAT is mostly done in coal mines by means of liming is less effective due to the use of lime to raise the pH lower only be pH neutral, but it does not reduce the metal content of Fe and Mn. Based on this, the authors conduct research at PT. Bukit Asam (Persero) Tbk. located in the village of Tanjung Enim, Lawang Kidul District, Muara Enim District, South Sumatra Province to analyze the effectiveness of the use of fly ash as an adsorbent in neutralizing AAT. Application use of fly ash in laboratory scale with a volume of $250 \mathrm{ml}$ AAT showed that the addition of mass fly ash and the stirring speed increased $\mathrm{pH}$ and decreased concentrations of Fe and Mn metal. Fly ash containing coal main mineral compound that is quartz. ( $\left.\mathrm{SiO}_{2}\right)$ and mullite $\left(\mathrm{Al}_{6} \mathrm{Si}_{2} \mathrm{O}_{13}\right.$ ), which acts on the adsorption process between heavy metal with adsorbent fly ash in aqueous solutions. Based on the analysis, the effectiveness of the mass of fly ash to changes in $\mathrm{pH}$ levels on average by $63.11 \%$. Furthermore, the effectiveness of the mass of fly ash to changes in the concentration of Fe on average by $85.95 \%$, while the effectiveness of the mass of fly ash to changes in the concentration of Mn metal by an average of $81.77 \%$. Therefore, Fe metal adsorption capacity greater than Mn metal adsorption capacity ie metal adsorption capacity of $4.938 \mathrm{mg} \mathrm{Fe} / \mathrm{g}$ whereas Mn metal adsorption capacity of $4.296 \mathrm{mg} / \mathrm{g}$ following the model of Freundlich adsorption isotherm.
\end{abstract}

Keywords: Fly Ash, Acid Mine Drainage, Adsorben 


\section{PENDAHULUAN}

Fly ash adalah bahan baku potensial yang dapat digunakan sebagai adsorben murah. Beberapa penelitian telah dilakukan guna menetralisir kandungan Air Asam Tambang (AAT), salah satunya melalui proses adsorpsi. Proses adsorpsi merupakan salah satu alternatif pengolahan yang sangat diminati karena selain dapat menyisihkan parameter pencemar, proses adsorpsi tidak rumit dalam pengerjaan dan minim terhadap biaya. Berdasarkan struktur padatan yang berpori dan memiliki rongga-rongga serta stabilitas termal yang besar, material mirip zeolit dapat difungsikan sebagai logam katalis atau adsorben (Bacrun Sutrisno dkk, 2014). Pada lokasi penelitian, penanganan AAT dilakukan secara kuratif yaitu mengolah AAT dengan cara pemberian batu kapur. Hal ini kurang efektif karena penggunaan kapur hanya untuk meningkatkan $\mathrm{pH}$ rendah menjadi $\mathrm{pH}$ netral, dan tidak dapat menurunkan kandungan logam $\mathrm{Fe}$ dan $\mathrm{Mn}$. Berdasarkan hal tersebut, maka dilakukan penelitian dengan menganalisis karakteristik adsorben sehingga pemanfaataan fly ash dapat sebagai adsorben dalam menetralisir AAT dengan efektif.

Adapun tujuan penelitian ini adalah sebagai berikut:

1. Menganalisis karakteristik adsorben dengan pengujian X-Ray Difraction (XRD) dan Scanning Electron Microscopy (SEM) sebelum dan sesudah dilakukan percobaan di laboratorium.

2. Menganalisis efektifitas massa adsorben (5,10 dan 12 gram) dan kecepatan pengadukan (30 dan 45 rpm) dalam menetralisir kandungan AAT.

3. Menganalisis kapasitas adsorpsi logam Fe dan Mn pada adsorben sekaligus menentukan pola isotherm adsorpsi berdasarkan pola isotherm Langmuir dan Freundlich.

Dalam perkembangan penelitian, terdapat material yang dapat digunakan dalam mentralisir AAT yaitu dengan memanfaatkan abu sisa pembakaran PLTU yaitu fly ash. Hasil analisis kandungan mineral menunjukkan bahwa fly ash mengandung oksida-oksida logam termasuk logam-logam berat dalam jumlah kecil. Oksida utama dari fly ash batubara adalah silika $\left(\mathrm{SiO}_{2}\right)$, alumina $\left(\mathrm{Al}_{2} \mathrm{O}_{3}\right)$ dan besi $\left(\mathrm{Fe}_{2} \mathrm{O}_{3}\right)$. Keberadaan komponen silika dan alumina memungkinkan $f l y$ ash untuk dapat disintesis menjadi material yang strukturnya mirip dengan zeolit atau dikenal dengan zeolite like material (ZLM). Struktur zeolit yang berpori merupakan sifat yang dapat dimanfaatkan sebagai material adsorben suatu bahan pencemar yang dikeluarkan dari suatu industri (Ananda Fauzan et. al, 2010).

Penggunaan fly ash telah banyak dilakukan pada beberapa penelitian dalam menetralisir AAT, antara lain:

1. Paul F. Ziemkiewicz (2006) Fly ash batubara dari proses pembakaran FBC (fluidzed bed combustion) umum digunakan untuk mengontrol air asam tambang di West Virginia Coal Mines proses pengolahan tergolong sukses walaupun masih ada beberapa hal yang menjadi perhatian seperti kandungan element racun yang terkandung pada abu batubara.

2. W.M Gitari, et.al. (2005) Penggunaan abu batubara efektif dalam menaikan $\mathrm{pH}$ air asam dari asam $\mathrm{pH} 2-3$ menjadi netral dan menunjukkan pengurangan kadar logam yang semakin besar sesuai dengan lamanya waktu kontak.

3. Keley Reynolds (2004) Penggunaan abu batubara untuk pengolahan air asam tambang dengan menggunakan column test skala laboratorium menunjukkan adanya perubahan $\mathrm{pH}$ dan penurunan logam berat yang signifikan.

4. Lesly F. Petrik et.al. (2003) Fly ash batubara direaksikan langsung dengan air asam tambang menunjukkan kenaikan $\mathrm{pH}$ dan penurunan pada kandungan logam berat.

5. Isna Syauqiah et.al. (2011) menunjukkan bahwa semakin besar kecepatan pengadukan, lama waktu kontak dan pemanasan yang digunakan semakin meningkat penurunan kadar Fe karena proses penyerapan adsorbat oleh adsorben menjadi lebih baik. Penurunan kadar Fe terbesar terlihat pada kecepatan pengadukan 90 rpm dan waktu aduk 60 menit

6. Riwandi dan Ali Munawar (2012) Abu batubara berhasil menetralkan pH air asam dalam waktu inkubasi tertentu dan menunjukkan kestabilan selama waktu 30 hari inkubasi.

7. Firman Gunawan, et.al (2014). Penelitian dan Pengembangan Sistem Pengelolaan Air Asam Tambang di Lati Mine Operation.

8. Novia, et.al. (2013) Studi pembuatan adsorben dari fly ash dilakukan dengan perlakuan refluks dan aktivasi menunjukkan bahwa fly ash dapat mengadsorbsi logam besi (Fe) dalam air.

9. Bachrun Sutrisno, et.al. (2013) menunjukkan bahwa karakteristik fly ash pada uji coba terlihat mempunyai kemampuan adsorpsi dalam mengurangi konsentrasi zat warna tekstil.

10. Ari Dwi Cahyono dan Tuhu Agung R. (2014) menunjukkan bahwa fly ash batubara dapat menurunkan parameter COD. Semakin lama waktu kontak dan semakin banyak massa adsorben maka prosentase penyisihan COD semakin meningkat.

11. Nivarida Hidayanti et.al. (2015) menunjukkan bahwa efisiensi proses adsorpsi untuk air kolong muda dalam penyisihan Fe dan Mn sebesar 94,04\% dan 99,64\%. 


\section{METODOLOGI PENELITIAN}

Metode pengambilan data yang dilakukan pada penelitian ini meliputi studi literatur dan penelitian lapangan serta penelitian laboratorium. Studi literatur dilakukan dengan mendapatkan informasi yang berkaitan dengan penelitian sehingga diperoleh data sekunder yang dijadikan acuan dalam penyusunan penulisan. Penelitian lapangan dilakukan pengambilan sampel sebagai data primer adalah AAT yang berasal dari inlet Kolam Pengendapan Lumpur (KPL) Galian Pit 1 Barat dan KPL Temporary Stockpile Pit 3 Barat (Lampiran A) yang dilakukan pengukuran awal pH dengan kertas lakmus, sedangkan sampel fly ash berasal dari electrostatic precipitator di PLTU TE 3x10 MW Banko Barat. Selanjutnya penelitian dalam skala laboratorium dengan memanfaatkan fly ash sebagai adsorben logam Fe dan Mn dalam menetralisir AAT melalui mekanisme adsorpsi secara batch. Pengujian dilakukan untuk mendeskripsikan kondisi pada variasi setiap parameter, sehingga dapat diperoleh kondisi optimal dalam menetralisir AAT.

Treatment yang dilakukan pada skala laboratorium menggunakan alat jart test dengan kecepatan pengadukan 30 dan 45 rpm. Dalam proses jart test, dilakukan pengadukan agar adsorben tersebar lebih merata dan seluruh permukaan adsorben dapat kontak dengan AAT. Hasil pengujian menunjukkan bahwa fly ash dapat menaikkan angka pH AAT serta menurunkan kandungan logam Fe dan Mn. Volume AAT yang digunakan sebanyak $250 \mathrm{ml}$ dengan konsentrasi Fe dalam pengujian adalah $12,18 \mathrm{mg} / \mathrm{l}$ dan $8,15 \mathrm{mg} / \mathrm{l}$ sedangkan konsentrasi $\mathrm{Mn}$ dalam pengujian adalah 7,73 $\mathrm{mg} / \mathrm{l} \mathrm{dan}$ $7,78 \mathrm{mg} / \mathrm{l}$. Dosis adsorben yang digunakan bervariasi yaitu 5, 10 dan 12 gram. Kontrol terhadap perubahan setiap parameter setelah pemberian treatment dilakukan dengan skema sebagai berikut:

a) $\mathrm{pH} \quad$ : kontrol dilakukan setiap 15, 30 dan 45 menit

b) Fe dan Mn : kontrol dilakukan pada waktu ke 45 menit

Parameter yang digunakan dalam pengujian di laboratorium yaitu pengujian kandungan AAT yang terdiri dari $\mathrm{pH}$, logam Fe dan Mn, sedangkan pengujian kandungan fly ash terdiri dari pengujian XRD dan SEM.

Selanjutnya tahapan metode analisis data penelitian ini menggunakan metode deskriptif kuantitatif yang terdiri dari :

a) Analisis perubahan morfologi dan kandungan fly ash sebelum dan sesudah dilakukan pengujian sehingga terjadi perubahan kandungan AAT.

b) Analisis pengaruh massa fly ash dan kecepatan pengadukan terhadap perubahan kandungan AAT.

c) Analisis regresi linier kapasitas adsorpsi logam Fe dan Mn dengan pola isoterm Langmuir dan Freundlich.

\section{HASIL DAN PEMBAHASAN}

AAT yang digunakan sebagai sampel pengujian berasal dari inlet KPL Penambangan Banko yang diambil secara grab pada 8 lokasi. Berdasarkan hasil pengujian kandungan AAT, maka konsentrasi pengujian lokasi sampel pada penelitian ini difokuskan di 2 KPL yaitu KPL Galian Pit 1 Barat (disebut C1) dan KPL Temporary Stockpile Pit 3 Barat (disebut C2). Lokasi ini dipilih karena pada lokasi tersebut mengandung AAT dengan kadar pH rendah yaitu 2,91 dan 3,17 dan konsentrasi logam Fe dan Mn yang tinggi diatas ambang yaitu konsentrasi Fe 12,17 mg/l dan 8,15 mg/l sedangkan konsentrasi Mn yaitu 7,73 mg/l dan 7,78 mg/l (Tabel 1).

Tabel 1. Hasil Pengujian AAT di KPL Penambangan Banko

\begin{tabular}{llcccc}
\hline No. & \multicolumn{1}{c}{ Lokasi Sampel } & $\mathrm{pH}$ & $\begin{array}{c}\mathrm{TSS} \\
(\mathrm{mg} / \mathrm{L})\end{array}$ & $\begin{array}{c}\mathrm{Fe} \\
(\mathrm{mg} / \mathrm{L})\end{array}$ & $\begin{array}{c}\mathrm{Mn} \\
(\mathrm{mg} / \mathrm{L})\end{array}$ \\
\hline 1. & Inlet KPL Galian Pit 1 Barat & 2,91 & 18 & 12,17 & 7,73 \\
2. & Inlet KPL Temporary Stockpile Pit 3 Barat & 3,17 & 68,00 & 8,15 & 7,78 \\
3. & Inlet KPL Galian Pit 1 Timur & 3,52 & 15,00 & 0,95 & 5,29 \\
4. & Inlet KPL Timbunan Pit 1 Utara & 3,47 & 4,00 & 2,90 & 8,29 \\
5. & Inlet KPL Galian Pit 3 Barat & 3,42 & 1,00 & 0,45 & 3,88 \\
6. & Inlet KPL Timbunan Pit 1 Timur & 4,81 & 3,00 & 0,22 & 2,66 \\
7. & Inlet KPL Timbunan Pit 3 Timur & 3,86 & 61,00 & 0,29 & 1,91 \\
8. & Inlet KPL Timbunan Pit 3 Barat & 4,02 & 58,00 & 1,98 & 0,64 \\
Baku mutu SK Gubernur Sumatera Selatan No. 18 & & & & 7 \\
Tahun 2005 tentang Pertambangan Batubara & $6-9$ & 300 & 7 & 5 \\
\hline
\end{tabular}

Tahapan analisis pada penelitian ini yaitu:

1. Karakterisasi adsorben dengan melakukan analisis kandungan fly ash dengan uji XRD dan permukaan fly ash dengan uji SEM sebelum dan sesudah pengujian.

2. Efektifitas kinerja adsorben terhadap perubahan kandungan AAT.

3. Kapasitas adsorpsi logam Fe dan Mn dengan pola isotherm Freundlich dan Langmuir. 


\subsection{Karakterisasi Adorben Fly Ash dan Pembahasan 3.1.1 Hasil Pengujian XRD}

Pada hasil pengujian XRD pada fly ash PLTU Banko bertujuan untuk mengetahui karakteristik mineral penyusun fly ash. Berdasarkan hasil uji XRD terlihat bahwa hampir di setiap senyawa mineral yang terbentuk terdapat mineral utama yaitu kuarsa $\left(\mathrm{SiO}_{2}\right)$ dan mullite $\left(\mathrm{Al}_{6} \mathrm{Si}_{2} \mathrm{O}_{13}\right)$. Keterdapatan mineral kuarsa dan mullite pada fly ash batubara sejalan dengan hasil penelitian yang telah dilakukan oleh Musyoka (2009) tentang adanya senyawa kuarsa $\left(\mathrm{SiO}_{2}\right)$ dan mullite $\left(\mathrm{Al}_{6} \mathrm{Si}_{2} \mathrm{O}_{13}\right)$ pada fly ash batubara. Mineral silika dan alumina menjadikan fly ash sebagai mineral aluminosilikat yang dapat menyerap logam Fe dan Mn. Silika dan alumina memiliki sisi polar dengan gugus aktif hidroksil (-OH) apabila dalam larutan mengandung air. Selain sebagai mineral aluminosilikat, fly ash juga memiliki kandungan mineral karbonat pada fly ash seperti aragonite $\left(\mathrm{CaCO}_{3}\right)$, periclase $(\mathrm{MgO})$ dan thomsonite $\left(\mathrm{NaCa}_{2}\left(\mathrm{Al}_{5} \mathrm{Si}_{5}\right) \mathrm{O}_{20}\right.$.

Hasil uji XRD pada fly ash menunjukkan bahwa karakteristik mineral yang terbentuk pada fly ash adalah bentuk kristal. Hasil difaktrogram terdiri dari mineral kuarsa, hematit, mullite, anhidrit, periklas, aragonite, rutile, glossularite dan vermicularite. Berdasarkan hasil uji XRD terlihat bahwa hampir di setiap senyawa mineral yang terbentuk terdapat mineral utama yaitu kuarsa $\left(\mathrm{SiO}_{2}\right)$ dan mullite $\left(\mathrm{Al}_{6} \mathrm{Si}_{2} \mathrm{O}_{13}\right)$. Keberadaan kuarsa $\left(\mathrm{SiO}_{2}\right)$ dalam fly ash terbentuk 3 puncak utama dengan sudut $2 \theta=20,90,26,76$ dan 50,43 serta keberadaan mineral mullite $\left(\mathrm{Al}_{6} \mathrm{Si}_{2} \mathrm{O}_{13}\right)$ terbentuk 4 puncak dengan sudut $2 \theta=33,38,36,73,39,5$ dan 40,48 (Gambar 1).

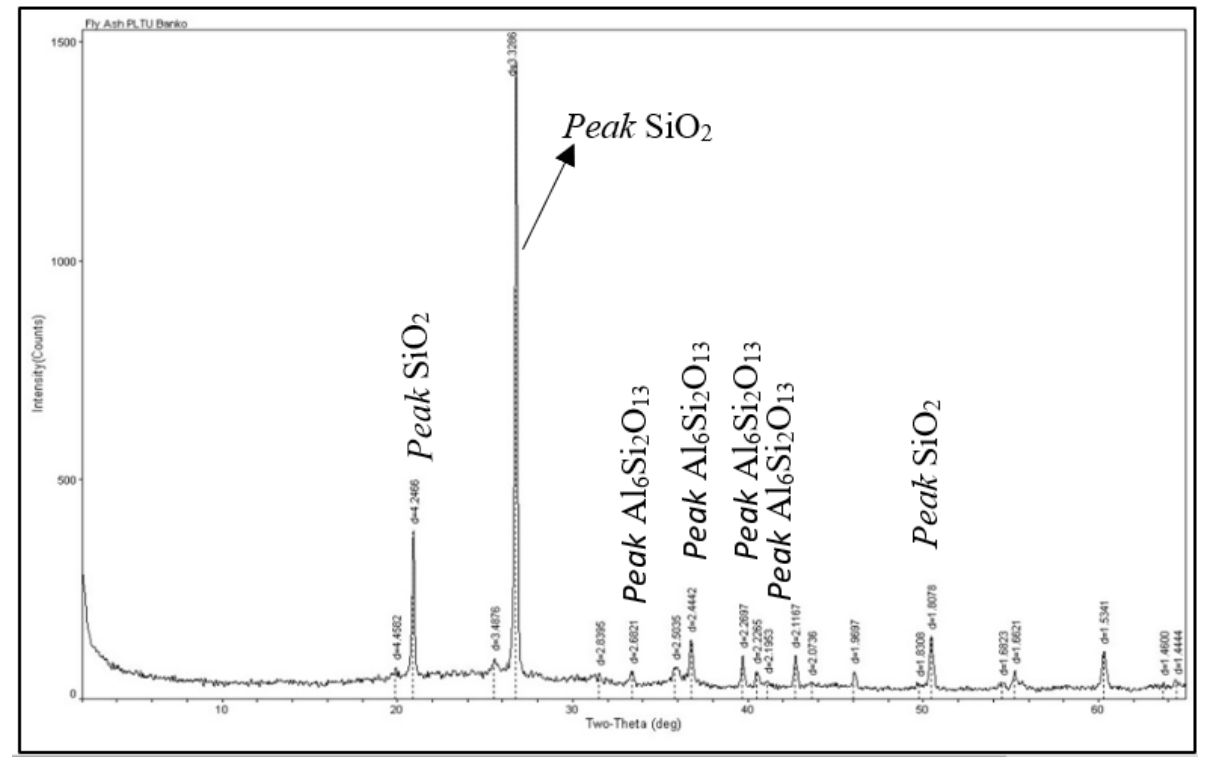

Gambar 1. Pola Difraksi Hasil Uji XRD Fly Ash Batubara Sebelum Percobaan Laboratorium

Berdasarkan hasil difaktogram hasil uji XRD sesudah percobaan terlihat bahwa terdapat peak-peak baru yang menunjukkan adanya mineral baru penyusun fly ash (Gambar 2). Mineral baru tersebut terdiri dari :

1. Illite $\left(\left(\mathrm{K}, \mathrm{H}_{3} \mathrm{O}\right)(\mathrm{Al}, \mathrm{Mg}, \mathrm{Fe})_{2}(\mathrm{Al}, \mathrm{Si})_{4} \mathrm{O}_{10}\left[(\mathrm{OH})_{2}, \mathrm{H}_{2} \mathrm{O}\right]\right)$ terdapat pada sudut $2 \theta=8,80$.

2. Halotrichite $\left(\mathrm{Fe}^{+2} \mathrm{Al}_{2}\left(\mathrm{SO}_{4}\right)_{4} \cdot 22 \mathrm{H}_{2} \mathrm{O}\right)$ terdapat pada sudut $2 \theta=25,58$.

3. Alunite $\left(\mathrm{KAl}_{3}\left(\mathrm{SO}_{4}\right)_{2}(\mathrm{OH})_{6}\right)$ terdapat pada sudut $2 \theta=29,66$.

4. Rhodocrosite $\left(\mathrm{MnCO}_{3}\right)$ terdapat pada sudut $2 \theta=31,47$.

5. Antigorite $\left((\mathrm{Mg}, \mathrm{Fe})_{3} \mathrm{Si}_{2} \mathrm{O}_{5}(\mathrm{OH})_{4}\right)$ terdapat pada sudut $2 \theta=36,68$.

6. Manganite $(\mathrm{MnO}(\mathrm{OH}))$ terdapat pada sudut $2 \theta=39,66$.

7. Bayerite $\left(\mathrm{Al}(\mathrm{OH})_{3}\right.$ (monoclinic) $)$ terdapat pada sudut $2 \theta=40,48$.

8. Lithioporite $\left((\mathrm{Al}, \mathrm{Li}) \mathrm{Mn}^{+4} \mathrm{O}_{2}(\mathrm{OH})_{2}\right)$ terdapat pada sudut $2 \theta=48,30$.

9. Rutile $\left(\mathrm{TiO}_{2}\right)$ terdapat pada sudut $2 \theta=54,43$.

Pada Gambar 3 terlihat bahwa adanya peak-peak baru yang muncul dalam komponen fly ash berdasarkan hasil XRD setelah dilakukan percobaan pencampuran dengan AAT. Hal ini menunjukkan bahwa telah terjadi proses adsorpsi antara mineral silika dan alumina dengan logam Fe dan Mn. Silika dan alumina menjadikan fly ash sebagai mineral aluminosilikat yang memiliki sisi polar dengan gugus aktif hidroksil (-OH) apabila dalam larutan mengandung air. Berdasarkan hasil pengujian XRD sebelum percobaan adanya gugus hidroksil pada fly ash yaitu senyawa mineral halloysite $\left(\mathrm{Al}_{2} \mathrm{Si}_{2} \mathrm{O}_{5}(\mathrm{OH})_{4}\right)$, kaolinite $\left(\mathrm{AlSi}_{2} \mathrm{O}_{5}(\mathrm{OH})_{4}\right)$, diaspore $(\mathrm{AlO}(\mathrm{OH}))$ dan vermiculite $\left((\mathrm{Mg}, \mathrm{Fe}, \mathrm{Al})_{3}(\mathrm{Al}, \mathrm{Si})_{4} \mathrm{O}_{10}\right.$ $\left.(\mathrm{OH})_{2}\right)$. Gugus hidroksil ini merupakan komponen yang berperan proses adsorpsi antara logam berat dengan adsorben fly ash. Ion-ion logam yang bermuatan positif menyebabkan ion-ion logam terserap pada sisi material yang bersifat polar. Sehingga ketika gugus aktif hidroksil direaksikan dengan AAT secara otomatis gugus -OH akan melepaskan diri dari strukturnya dan langsung berikatan dengan logam Fe dan Mn. 


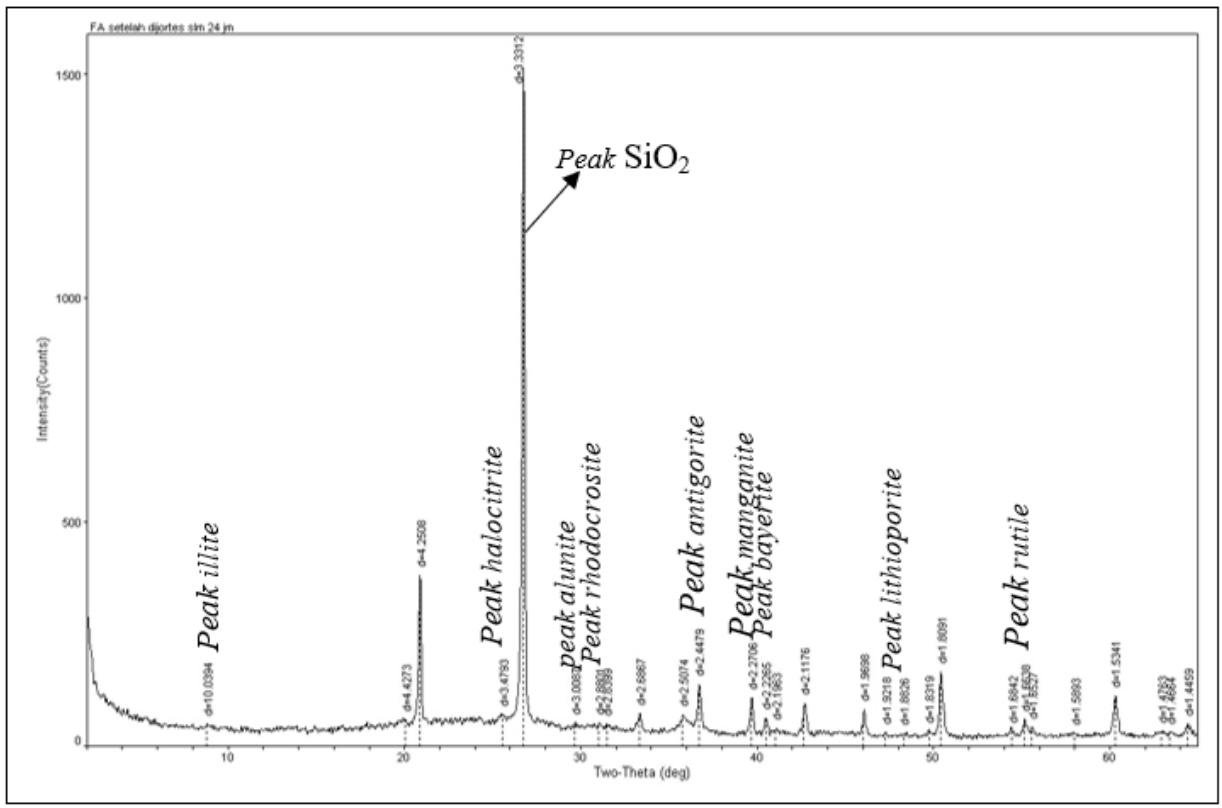

Gambar 2. Pola Difraksi Hasil Uji XRD Fly Ash Batubara Sesudah Percobaan Laboratorium

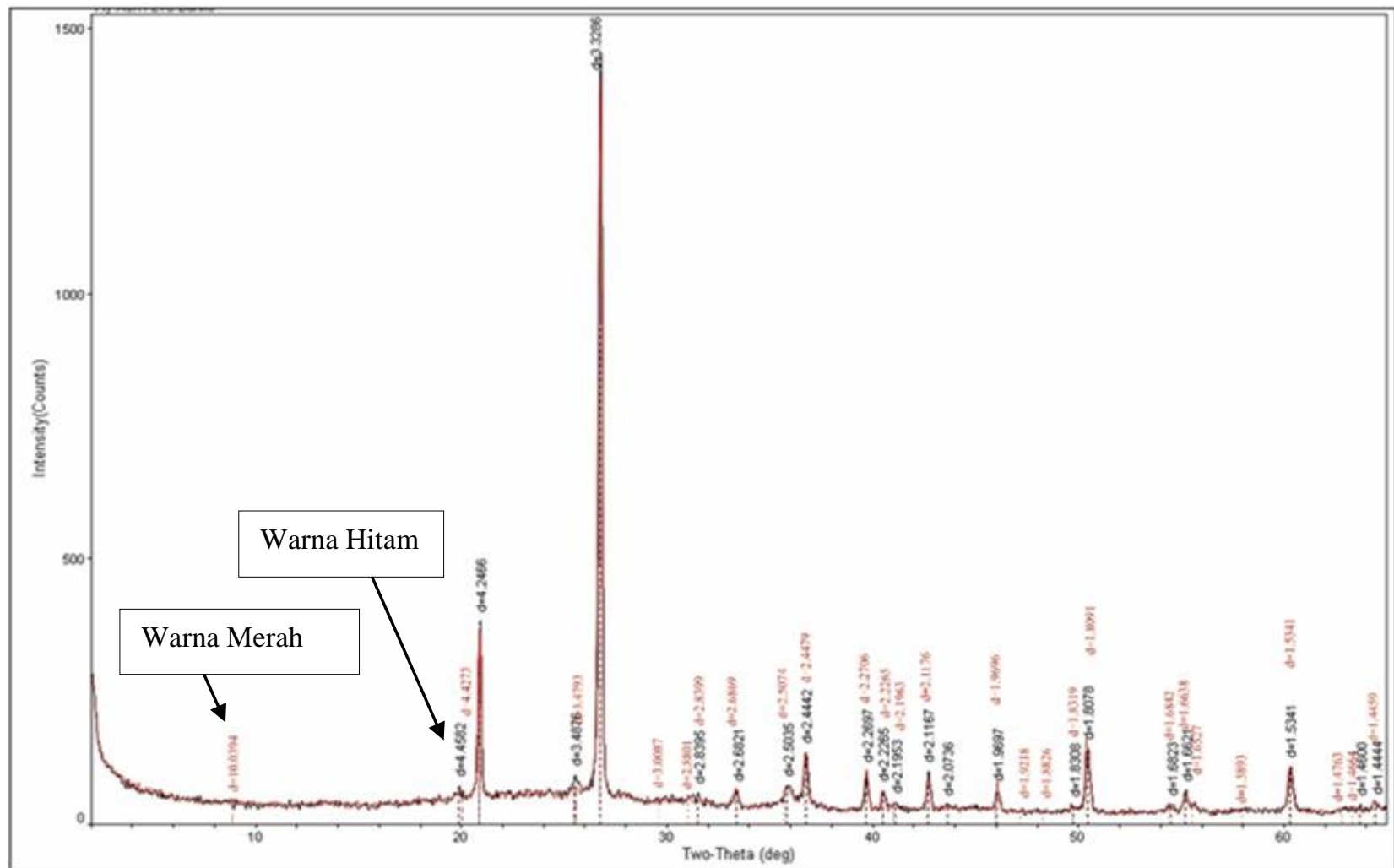

Gambar 3. Difaktogram Hasil XRD Fly Ash Batubara. Kurva Fly Ash Sebelum Percobaan (warna hitam), kurva Fly Ash Sesudah Percobaan (warna merah)

Oleh karena itu, terlihat bahwa peak-peak baru yang muncul dalam hasil XRD merupakan ikatan senyawa mineral yang merupakan ikatan senyawa antara logam Fe dengan gugus aktif hidroksil serta logam Mn dengan gugus aktif hidroksil. Mineral-mineral baru tersebut yang ditunjukkan dengan adanya peak-peak baru antara lain :

a. Illite $\left(\mathrm{K}, \mathrm{H}_{3} \mathrm{O}\right)(\mathrm{Al}, \mathrm{Mg}, \mathrm{Fe})_{2}(\mathrm{Al}, \mathrm{Si}) 4 \mathrm{O}_{10}\left[(\mathrm{OH}) 2 \mathrm{H}_{2} \mathrm{O}\right]$ : unsur Fe terikat dengan gugus aktif $(-\mathrm{OH})$.

b. Antigorite $\left((\mathrm{Mg}, \mathrm{Fe})_{3} \mathrm{Si}_{2} \mathrm{O}_{5}(\mathrm{OH})_{4}\right)$ : unsur Fe teradsorpsi oleh gugus aktif $(-\mathrm{OH})$.

c. Manganite $(\mathrm{MnO}(\mathrm{OH}))$ : logam $\mathrm{Mn}$ teradsorpsi oleh gugus aktif $(-\mathrm{OH})$.

d. Lithioporite $\left((\mathrm{Al}, \mathrm{Li}) \mathrm{Mn}^{+4} \mathrm{O}_{2}(\mathrm{OH})_{2}\right)$ : $\mathrm{Mn}$ berikatan dengan gugus aktif $\mathrm{OH}$. 


\subsubsection{Hasil Uji SEM}

Untuk mengetahui karakteristik fly ash maka dilakukan pengujian SEM. Pengujian ini dilakukan dengan tujuan untuk mengetahui struktur permukaan fly ash. Berdasarkan hasil pengujian menunjukkan bahwa fly ash merupakan padatan yang berpori dan memiliki rongga-rongga. Pada penelitian ini dilakukan pengujian SEM sebelum dan sesudah dilakukan percobaan laboratorium. Pada struktur permukaan fly ash sebelum dilakukan percobaan pencampuran AAT menunjukkan keterdapatan pori pada permukaan fly ash yang dapat dimanfaatkan sebagai situs aktif yang dapat menyerap logam Fe dan Mn. Selanjutnya pada struktur permukaan fly ash sesudah dilakukan percobaan laboratorium terlihat susunan pori-pori pada permukaan fly ash semakin banyak di setiap komponen fly ash. Pori yang terbentuk menjadi semakin besar, hal ini menandakan terjadi pertambahan luas permukaan pada fly ash. Pembentukan pori yang semakin besar ini terjadi karena AAT bersifat korosif dapat menghancurkan bagian dalam fly ash dan meningkatkan volume mikropori, serta menurunkan distribusi ukuran partikel (Bada and Potgieter-Vermaak, 2008). Selain muncul pori baru, pada dasarnya keterdapatan silika dan alumina merupakan media berpori yang berpotensi digunakan sebagai adsorben untuk ion-ion logam. Akibat rusaknya lapisan permukaan fly ash sesudah percobaan ini maka gugus-gugus aktif yang terdapat didalamnya seperti silika dan alumina keluar kepermukaan (Gambar 4). Silika dan alumina merupakan media berpori dan sebagai gugus aktif yang berpotensi sebagai adsorben ion-ion logam. Sebagai gugusgugus aktif, silika dan alumina akan keluar kepermukaan apabila terjadi kerusakan pada lapisan permukaan fly ash sehingga dapat mengadsorpsi logam Fe dan Mn.

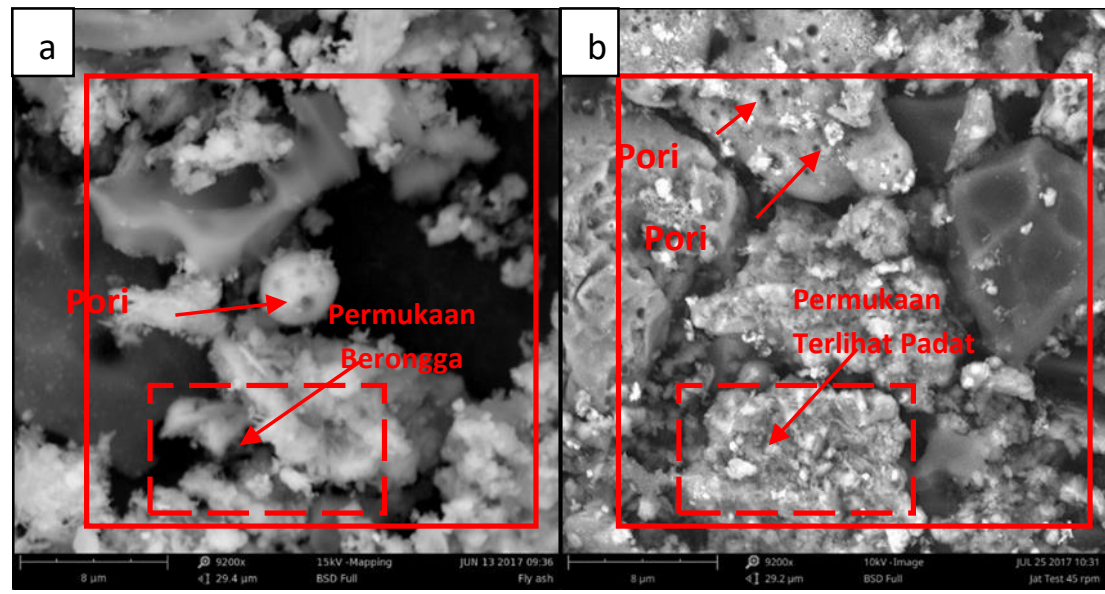

Gambar 4. (a) Hasil Uji SEM Fly Ash Sebelum Percobaan Laboratorium dengan perbesaran 9200x, (b) Hasil Uji SEM Fly Ash Setelah Percobaan Laboratorium dengan Perbesaran 9200x

Selain keterdapatan pori, perbedaan yang cukup signfikan pada Gambar 4 menggambarkan bahwa adsorben fly ash telah mengadsorpsi logam Fe dan Mn pada permukaan pori yaitu pada permukaan pori fly ash sebelum dilakukan percobaan terlihat sangat berongga sedangkan pada permukaan pori fly ash sesudah percobaan terlihat bahwa ronggarongga telah terisi oleh banyak material dan padat. Hal ini menunjukkan bahwa material-material tersebut masuk dan melekat pada permukaan adsorben.

\subsection{Efektifitas kinerja adsorben terhadap perubahan kandungan AAT}

\subsubsection{Hasil Pengujian pH dan Pembahasan}

Perubahan $\mathrm{pH}$ AAT berdasarkan variasi percobaan menunjukkan perubahan yang sebanding dengan penambahan perlakukan massa fly ash ataupun penambahan kecepatan pengadukan (Tabel 2).

Tabel 2. Data Perubahan Kadar pH Berdasarkan Penambahan Dosis Fly Ash dan Kecepatan Pengadukan

\begin{tabular}{|c|c|c|c|c|c|c|c|}
\hline \multicolumn{8}{|c|}{ Kadar pH } \\
\hline \multirow{3}{*}{\multicolumn{2}{|c|}{$\begin{array}{c}\text { Berat Fly Ash } \\
\text { Kecepatan } \\
\text { Waktu (menit) }\end{array}$}} & \multicolumn{6}{|c|}{5 gram } \\
\hline & & \multicolumn{3}{|c|}{$30 \mathrm{rpm}$} & \multicolumn{3}{|c|}{$45 \mathrm{rpm}$} \\
\hline & & 15 & 30 & 45 & 15 & 30 & 45 \\
\hline Sampel & pH Awal & & & & & & \\
\hline $\mathrm{C} 1$ & 2,91 & 3,78 & 4,35 & 4,49 & 5,07 & 6,09 & 6,32 \\
\hline $\mathrm{C} 1$ & 2,91 & 4,16 & 4,48 & 4,50 & 5,56 & 6,14 & 6,33 \\
\hline $\mathrm{C} 1$ & 2,91 & 4,56 & 4,60 & 4,73 & 6,74 & 7,47 & 7,68 \\
\hline $\mathrm{C} 2$ & 3,44 & 5,09 & 6,37 & 6,96 & 7,82 & 8,08 & 8,03 \\
\hline $\mathrm{C} 2$ & 3,44 & 5,25 & 6,47 & 6,94 & 8,08 & 8,16 & 8,19 \\
\hline $\mathrm{C} 2$ & 3,44 & 5,40 & 6,47 & 6,96 & 7,66 & 7,79 & 7,85 \\
\hline
\end{tabular}

\section{Kadar pH}

Alieftiyani Paramita Gobel, Edy Nursanto, Wawong Dwi Ratminah 


\begin{tabular}{|c|c|c|c|c|c|c|c|}
\hline \multirow{4}{*}{\multicolumn{2}{|c|}{$\begin{array}{c}\text { Berat Fly Ash } \\
\text { Kecepatan } \\
\text { Waktu (menit) }\end{array}$}} & \multirow{2}{*}{\multicolumn{6}{|c|}{10 gram }} \\
\hline & & & & & & & \\
\hline & & \multicolumn{3}{|c|}{$30 \mathrm{rpm}$} & \multicolumn{3}{|c|}{$45 \mathrm{rpm}$} \\
\hline & & \multirow[t]{2}{*}{15} & \multirow[t]{2}{*}{30} & \multirow[t]{2}{*}{45} & \multirow[t]{2}{*}{15} & \multirow[t]{2}{*}{30} & \multirow[t]{2}{*}{45} \\
\hline Sampel & pH Awal & & & & & & \\
\hline $\mathrm{C} 1$ & 2,91 & 4,79 & 6,34 & 6,63 & 7,41 & 7,88 & 7,94 \\
\hline $\mathrm{C} 1$ & 2,91 & 5,09 & 6,98 & 7,24 & 8,09 & 8,20 & 8,16 \\
\hline $\mathrm{C} 1$ & 2,91 & 6,92 & 7,81 & 7,90 & 8,10 & 8,51 & 8,59 \\
\hline $\mathrm{C} 2$ & 3,44 & 6,69 & 7,73 & 7,94 & 8,59 & 8,73 & 8,68 \\
\hline $\mathrm{C} 2$ & 3,44 & 7,20 & 7,93 & 8,11 & 8,76 & 8,82 & 8,82 \\
\hline $\mathrm{C} 2$ & 3,44 & 8,28 & 8,27 & 8,29 & 8,53 & 8,59 & 8,60 \\
\hline
\end{tabular}

lanjutan Tabel 2

\begin{tabular}{|c|c|c|c|c|c|c|c|}
\hline \multicolumn{8}{|c|}{ Kadar pH } \\
\hline \multirow{3}{*}{\multicolumn{2}{|c|}{$\begin{array}{c}\text { Berat Fly Ash } \\
\text { Kecepatan } \\
\text { Waktu (menit) }\end{array}$}} & \multicolumn{6}{|c|}{12 gram } \\
\hline & & \multicolumn{3}{|c|}{$30 \mathrm{rpm}$} & \multicolumn{3}{|c|}{$45 \mathrm{rpm}$} \\
\hline & & 15 & 30 & 45 & 15 & 30 & 45 \\
\hline \multicolumn{8}{|c|}{ Sampel pH Awal } \\
\hline $\mathrm{C} 1$ & 2,91 & 8,08 & 8,42 & 8,58 & 7,68 & 8,14 & 8,19 \\
\hline $\mathrm{C} 1$ & 2,91 & 8,10 & 8,45 & 8,59 & 8,58 & 8,71 & 8,70 \\
\hline $\mathrm{C} 1$ & 2,91 & 8,34 & 8,51 & 8,71 & 8,70 & 8,69 & 8,69 \\
\hline $\mathrm{C} 2$ & 3,44 & 6,18 & 7,43 & 7,88 & 8,66 & 8,84 & 8,81 \\
\hline $\mathrm{C} 2$ & 3,44 & 6,75 & 7,63 & 7,96 & 8,73 & 8,89 & 8,87 \\
\hline $\mathrm{C} 2$ & 3,44 & 6,79 & 7,67 & 8,03 & 8,56 & 8,70 & 8,74 \\
\hline
\end{tabular}

Berdasarkan Tabel 2. menunjukkan bahwa adanya penambahan massa fly ash sangat berpengaruh terhadap perubahan pH AAT. Hasil pengujian diperoleh untuk massa 5 gram dengan kecepatan 30 rpm menunjukkan efektifitas kenaikan $\mathrm{pH}$ rata-rata mencapai 38,75\% yaitu dengan rentang dari $\mathrm{pH}$ awal 2,91 hingga 4,75 dan pH awal 3,44 hingga 5,62. Selanjutnya untuk massa 5 gram dengan kecepatan $45 \mathrm{rpm}$ menunjukkan rata-rata efektifitas kenaikan $\mathrm{pH}$ mencapai $55,22 \%$ yaitu dengan rentang dari $\mathrm{pH}$ awal 2,91 hingga 6,50 dan $\mathrm{pH}$ awal 3,44 hingga 7,68. Untuk massa 10 gram dengan kecepatan $30 \mathrm{rpm}$ menunjukkan efektifitas kenaikan $\mathrm{pH}$ rata-rata mencapai 55,38\% yaitu dengan rentang dari pH awal 2,91 hingga 6,52 dan $\mathrm{pH}$ awal 3,44 hingga 7,71. Selanjutnya untuk massa 10 gram dengan kecepatan $45 \mathrm{rpm}$ menunjukkan efektifitas kenaikan $\mathrm{pH}$ rata-rata mencapai $62,18 \%$ yaitu dengan rentang dari pH awal 2,91 hingga 7,66 dan $\mathrm{pH}$ awal 3,44 hingga 8,72. Variasi massa 12 gram dengan kecepatan $30 \mathrm{rpm}$ menunjukkan efektifitas kenaikan $\mathrm{pH}$ rata-rata mencapai 59,20\% yaitu dengan rentang dari $\mathrm{pH}$ awal 2,91 hingga 7,10 dan pH awal 3,44 hingga 8,39. Selanjutnya untuk massa 12 gram dengan kecepatan 45 rpm menunjukkan efektifitas kenaikan $\mathrm{pH}$ rata-rata mencapai $63,11 \%$ yaitu dengan rentang dari $\mathrm{pH}$ awal 2,91 hingga 7,86 dan $\mathrm{pH}$ awal 3,44 hingga 8,89.

Analisis awal mengenai karakteristik adsorben fly ash dilanjutkan dengan menganalisis efektifitas kinerja adsorben yang dinyatakan dalam bentuk persen. Secara umum efektifitas menunjukkan sampai seberapa jauh tercapainya suatu tujuan yang telah ditentukan dengan semakin besar persentase target yang dicapai, makin tinggi efektifitasnya. Efektifitas kinerja adsorben dapat dipengaruhi oleh adanya penambahan massa fly ash dan kecepatan pengadukan. Adanya penambahan massa fly ash maka semakin banyak senyawa-senyawa silikat oksida dan memperluas situs-situs aktif dalam proses adsorpsi, sedangkan adanya peningkatan kecepatan pengadukan maka dapat mempercepat proses adsorpsi. Berdasarkan hasil perhitungan efektifitas tersebut menunjukkan bahwa perubahan $\mathrm{pH}$ yang paling efektif dalam percobaan ini yaitu pada massa fly ash 12 gram dengan kecepatan pengadukan 45 rpm yaitu rata-rata sebesar 63,11\%. Hal ini ditunjukkan pada Gambar 1 bahwa fly ash memiliki kandungan mineral karbonat seperti aragonite $\left(\mathrm{CaCO}_{3}\right)$, periclase $(\mathrm{MgO})$ dan thomsonite $\left(\mathrm{NaCa}_{2}\left(\mathrm{Al}_{5} \mathrm{Si}_{5}\right) \mathrm{O}_{20}\right)$ yang berfungsi sebagai senyawa alkali pembentuk suasana basa dalam larutan sehingga fly ash dapat meningkatkan pH AAT.

\subsubsection{Hasil Pengujian Fe dan Mn}

Hasil pengujian adsorpsi logam besi (Fe) menunjukkan penurunan konsentrasi yang cukup signifikan (Tabel 3). Hasil pengujian adsorpsi logam mangan (Mn) menunjukkan hasil yang cukup lama hingga berada pada konsentrasi di bawah ambang batas baku mutu air limbah (Tabel 4). Daya adsorpsi logam Mn sangat dipengaruhi oleh massa adsorben dan pH AAT. 
Tabel 3. Hasil Uji Adsorpsi Fly Ash Terhadap Logam Fe

\begin{tabular}{ccccccc}
\hline \multicolumn{7}{c}{ Konsentrasi Fe } \\
\hline Berat Fly Ash \\
Kecepatan \\
\cline { 2 - 7 } $\begin{array}{c}\text { Konsentrasi } \\
\text { Awal }\end{array}$ & \multicolumn{2}{c}{5 gram } & \multicolumn{7}{c}{10 gram } & \multicolumn{2}{c}{12 gram } \\
12,18 & $\mathrm{mg} / 1$ & $\mathrm{mg} / \mathrm{l}$ & $\mathrm{mg} / \mathrm{l}$ & $\mathrm{mg} / \mathrm{l}$ & $\mathrm{mg} / \mathrm{l}$ & $\mathrm{mg} / \mathrm{l}$ \\
\cline { 2 - 7 } 12,18 & 3,32 & 2,37 & 2,76 & 2,27 & 2,73 & 2,05 \\
12,18 & 2,66 & 2,33 & 2,73 & 3,27 & 3,34 & 2,93 \\
8,15 & 3,29 & 2,37 & 2,73 & 1,98 & 2,68 & 1,76 \\
8,15 & 2,50 & 1,64 & 3,88 & 2,27 & 2,94 & 2,05 \\
8,15 & 2,06 & 0,06 & 2,09 & 0,83 & 3,46 & 1,24 \\
& 1,10 & 0,44 & 1,01 & 0,40 & 3,56 & 0,21 \\
\hline
\end{tabular}

Tabel 4. Hasil Uji Adsorpsi Fly Ash Terhadap Logam Mn

\begin{tabular}{|c|c|c|c|c|c|c|}
\hline \multicolumn{7}{|c|}{ Konsentrasi Mn } \\
\hline \multirow{2}{*}{$\begin{array}{c}\text { Berat Fly Ash } \\
\text { Kecepatan }\end{array}$} & \multicolumn{2}{|c|}{5 gram } & \multicolumn{2}{|c|}{10 gram } & \multicolumn{2}{|c|}{12 gram } \\
\hline & $30 \mathrm{rpm}$ & $45 \mathrm{rpm}$ & $30 \mathrm{rpm}$ & $45 \mathrm{rpm}$ & $30 \mathrm{rpm}$ & $45 \mathrm{rpm}$ \\
\hline Konsentrasi & $\mathrm{mg} / \mathrm{l}$ & $\mathrm{mg} / \mathrm{l}$ & $\mathrm{mg} / \mathrm{l}$ & $\mathrm{mg} / \mathrm{l}$ & $\mathrm{mg} / \mathrm{l}$ & $\mathrm{mg} / \mathrm{l}$ \\
\hline 7,34 & 6,58 & 6,23 & 3,65 & 3,53 & 2,33 & 2,98 \\
\hline 7,34 & 6,74 & 5,58 & 3,55 & 2,40 & 2,94 & 1,66 \\
\hline 7,34 & 6,85 & 4,95 & 5,43 & 2,23 & 5,22 & 1,54 \\
\hline 7,78 & 1,66 & 1,60 & 1,26 & 1,02 & 1,48 & 0,55 \\
\hline 7,78 & 1,98 & 1,41 & 1,41 & 0,71 & 0,99 & 0,83 \\
\hline 7,78 & 2,31 & 1,38 & 1,84 & 0,78 & 1,94 & 0,58 \\
\hline
\end{tabular}

Berdasarkan pengujian yang telah dilakukan pada Tabel 3 dan Tabel 4 menunjukkan kecenderungan penurunan konsentrasi logam Fe dan Mn yang tidak sebanding dengan adanya penambahan massa fly ash. Penurunan konsentrasi logam Fe dan Mn sebanding dengan kecepatan pengadukan. Efektifitas adsorpsi logam Fe berdasarkan jumlah massa fly ash dan kecepatan pengadukan dengan waktu kontak selama 45 menit adalah sebagai berikut:

a. Efektifitas adsorpsi massa fly ash 5 gram dengan kecepatan $30 \mathrm{rpm}$ adalah 75,74\% yaitu dari konsentrasi awal 12,18 $\mathrm{mg} / \mathrm{l}$ menjadi $2,95 \mathrm{mg} / \mathrm{l}$ dan $8,15 \mathrm{mg} / \mathrm{l}$ menjadi $1,97 \mathrm{mg} / \mathrm{l}$, sedangkan efektifitas adsorpsi massa fly ash 5 gram dengan kecepatan $45 \mathrm{rpm}$ adalah 85,95\% yaitu dari konsentrasi awal 12,18 mg/l menjadi 1,71 mg/l dan 8,15 mg/l menjadi $1,14 \mathrm{mg} / \mathrm{l}$.

b. Efektifitas adsorpsi massa fly ash 10 gram dengan kecepatan 30 rpm efektifitas adsorpsi logam Fe adalah $74,48 \%$ yaitu dari konsentrasi awal 12,18 mg/l menjadi 3,10 mg/l dan 8,15 mg/l menjadi 2,03 mg/l, sedangkan efektifitas adsorpsi massa fly ash 10 gram dengan kecepatan $45 \mathrm{rpm}$ adalah 82,55\% yaitu dari konsentrasi awal 12,18 mg/l menjadi $2,12 \mathrm{mg} / \mathrm{l}$ dan $8,15 \mathrm{mg} / \mathrm{l}$ menjadi $1,42 \mathrm{mg} / \mathrm{l}$.

c. Efektifitas adsorpsi massa fly ash 12 gram dengan kecepatan $30 \mathrm{rpm}$ efektifitas adsorpsi logam Fe adalah $67,66 \%$ yaitu dari konsentrasi awal 12,18 mg/l menjadi 3,93 mg/l dan 8,15 mg/l menjadi 2,63 mg/l sedangkan efektifitas adsorpsi massa fly ash 12 gram dengan kecepatan $45 \mathrm{rpm}$ adalah 83,62\% yaitu dari konsentrasi awal 12,18 mg/l menjadi $1,99 \mathrm{mg} / \mathrm{l}$ dan $8,15 \mathrm{mg} / \mathrm{l}$ menjadi $1,33 \mathrm{mg} / \mathrm{l}$.

Selanjutnya efektifitas adsorpsi logam Mn berdasarkan jumlah massa fly ash dan kecepatan pengadukan dengan waktu kontak selama 45 menit adalah sebagai berikut:

a. Efektifitas adsorpsi massa fly ash 5 gram dengan kecepatan $30 \mathrm{rpm}$ efektifitas adsorpsi logam Mn adalah 41,45\% yaitu dari konsentrasi awal 7,34mg/l hingga 4,29mg/l dan 7,78mg/l hingga 4,55mg/l sedangkan efektifitas adsorpsi massa fly ash 5 gram dengan kecepatan $45 \mathrm{rpm}$ adalah 52,54\% yaitu dari konsentrasi awal 7,34 mg/l hingga $3,48 \mathrm{mg} / \mathrm{l}$ dan $7,78 \mathrm{mg} / \mathrm{l}$ hingga $3,69 \mathrm{mg} / 1$.

b. Efektifitas adsorpsi massa fly ash 10 gram dengan kecepatan 30 rpm efektifitas adsorpsi logam Mn adalah $61,66 \%$ yaitu dari konsentrasi awal 7,34mg/l hingga 2,81mg/l dan 7,78mg/l hingga 2,98mg/l, efektifitas adsorpsi massa fly ash 10 gram dengan kecepatan $45 \mathrm{rpm}$ adalah 76,09\% yaitu dari konsentrasi awal 7,34 mg/l hingga 1,75mg/l dan $7,78 \mathrm{mg} / \mathrm{l}$ hingga $1,86 \mathrm{mg} / \mathrm{l}$.

c. Efektifitas adsorpsi massa fly ash 12 gram dengan kecepatan 30 rpm efektifitas adsorpsi logam Mn adalah 66,73\% yaitu dari konsentrasi awal 7,34mg/l hingga 2,44mg/l dan 7,78mg/l hingga 2,58mg/l sedangkan efektifitas adsorpsi massa fly ash 12 gram dengan kecepatan $45 \mathrm{rpm}$ adalah $81,77 \%$ yaitu dari konsentrasi awal 7,34 mg/l hingga $1,33 \mathrm{mg} / \mathrm{l}$ dan $7,78 \mathrm{mg} / \mathrm{l}$ hingga $1,41 \mathrm{mg} / 1$. 
Berdasarkan hasil percobaan tersebut di atas maka efektifitas adsorpsi logam Fe yaitu sebesar 85,95\% dengan variasi massa fly ash 5 gram dengan kecepatan 45 rpm sedangkan efektifitas adsorpsi logam Mn yaitu sebesar 81,77\% dengan variasi massa 12 gram dan kecepatan $45 \mathrm{rpm}$. Hasil penelitian ini menunjukkan hasil yang selaras dengan penelitian sebelumnya oleh Kulkamil et.al. (2013) bahwa fly ash merupakan salah satu alternatif adsorben pilihan yang efektif dengan persentase penyisihan mencapai 75-95\%. Hasil percobaan ini juga menunjukkan perbedaan adsorpsi antara logam Fe dan Mn, terlihat pada hasil analisis logam Mn menunjukkan bahwa adsorpsi lebih cepat terjadi jika jumlah massa fly ash lebih banyak atau dengan kata lain pada kondisi $\mathrm{pH}$ yang semakin basa. Hal ini dipengaruhi oleh kehadiran ion $\mathrm{H}^{+}$pada permukaan adsorben, sehingga ion logam berat saling berkompetisi. Berdasarkan tabel periodik, unsur Fe juga memiliki keelektronegatifan yang lebih besar dibandingkan Mn oleh karena itu diperoleh hasil bahwa persentase penyerapan logam Fe lebih tinggi dari logam Mn. Hal ini sejalan dengan penelitian Styumm dan Morgan (1981) mengatakan bahwa penghilangan logam Mn terlarut dari suatu larutan dapat dicapai pada pH tinggi kondisis teroksidasi yang sangat kuat. Oksidasi logam Mn secara abiotik sangat lambat pada pH kurang dari 8.

\subsection{Kapasitas Adsorpsi Logam Fe dan Mn}

Proses adsorpsi oleh suatu adsorben memiliki pola isoterm adsorpsi tertentu yang spesifik untuk mengetahui besarnya konsentrasi adsorbat optimum yang dapat diadsorpsi oleh adsorben fly ash. Hasil analisis data menunjukkan bahwa dalam menentukan pola adsorpsi isotherm yang cocok untuk proses penyerapan logam Fe dan Mn maka dilihat berdasarkan nilai koefisien korelasi $\left(\mathrm{R}^{2}\right)$. Pada proses adsorpsi logam Fe berdasarkan pola adsorpsi isoterm Freundlich nilai korelasi data $\left(\mathrm{R}^{2}\right)$ lebih besar yaitu 0,2317 (Tabel 5) sedangkan harga $\mathrm{R}^{2}$ berdasarkan adsorpsi isoterm Langmuir yaitu 0,0926 (Tabel 6).

Tabel 5. Nilai $\mathrm{R}^{2}$ Pola Isotherm Freundlich Adsorpsi Logam Fe dan Mn

\begin{tabular}{|c|c|c|c|c|c|c|c|}
\hline \multicolumn{8}{|c|}{ Isoterm Freundlich } \\
\hline \multirow{2}{*}{$\begin{array}{c}\mathrm{C}_{0} \\
(\mathrm{mg} / \mathrm{l})\end{array}$} & \multicolumn{3}{|c|}{$\begin{array}{c}\text { Logam Fe } \\
\text { Persamaan Regresi }\end{array}$} & \multirow{2}{*}{$\begin{array}{c}\mathrm{C}_{0} \\
(\mathrm{mg} / \mathrm{l}) \\
\end{array}$} & \multicolumn{3}{|c|}{$\begin{array}{c}\text { Logam Mn } \\
\text { Persamaan Regresi }\end{array}$} \\
\hline & $\mathbf{R}^{2}$ & $\mathbf{A X}$ & B & & $\mathbf{R}^{2}$ & $\mathbf{A X}$ & B \\
\hline 12,18 & 0,0002 & 0,0326 & $-0,5627$ & 7,34 & 0,6397 & $-0,8616$ & $-0,6331$ \\
\hline 8,15 & 0,2317 & $-0,2776$ & $-0,6936$ & 7,78 & 0,1737 & 0,3348 & $-0,7473$ \\
\hline
\end{tabular}

Tabel 6. Nilai $\mathrm{R}^{2}$ Model Isotherm Langmuir Adsorpsi Logam Fe dan Mn

\begin{tabular}{|c|c|c|c|c|c|c|c|}
\hline \multicolumn{8}{|c|}{ Isoterm Langmuir } \\
\hline \multirow{2}{*}{$\begin{array}{c}\mathrm{C}_{0} \\
(\mathrm{mg} / \mathrm{l})\end{array}$} & \multicolumn{3}{|c|}{$\begin{array}{c}\text { Logam Fe } \\
\text { Persamaan Regresi }\end{array}$} & \multirow{2}{*}{$\begin{array}{c}\mathrm{C}_{0} \\
(\mathrm{mg} / \mathrm{l}) \\
\end{array}$} & \multicolumn{3}{|c|}{$\begin{array}{c}\text { Logam Mn } \\
\text { Persamaan Regresi }\end{array}$} \\
\hline & $\mathbf{R}^{2}$ & AX & B & & $\mathbf{R}^{2}$ & $\mathbf{A X}$ & B \\
\hline 12,18 & 0,0001 & 0,1715 & 3,7091 & 7,34 & 0,4057 & $-39,84$ & 27,442 \\
\hline 8,15 & 0,0926 & $-0,7137$ & 6,7413 & 7,78 & 0,1296 & 1,4755 & 4,1907 \\
\hline
\end{tabular}

Nilai korelasi 0,2317 untuk logam Fe artinya bahwa hasil yang diperoleh mempunyai tingkat korelasi yang lemah, sedangkan dan 0,6397 untuk logam Mn artinya bahwa hasil yang diperoleh mempunyai tingkat korelasi yang cukup. Selanjutnya pada proses adsorpsi logam Mn berdasarkan pola adsorpsi isotherm Freundlich nilai korelasi data $\left(\mathrm{R}^{2}\right)$ lebih besar yaitu 0,6397 , sedangkan pola adsorpsi isotherm Langmuir nilai $\mathrm{R}^{2}$ yaitu 0,4057 . Selanjutnya pada proses adsorpsi logam Mn berdasarkan pola adsorpsi isotherm Freundlich nilai korelasi data $\left(\mathrm{R}^{2}\right)$ lebih besar yaitu 0,6397, sedangkan pola adsorpsi isotherm Langmuir nilai $\mathrm{R}^{2}$ yaitu 0,4057 . Setelah mengetahui nilai korelasi data maka dapat di ketahui kecocokan pola adsorpsi isotherm untuk mengetahui kapasitas logam Fe dan Mn. Berdasarkan persamaan isotherm Langmuir menunjukkan bahwa kapasitas adsorpsi maksimum logam Fe sebesar 1,401 mg/g dengan nilai korelasi ( $\mathrm{R}^{2}$ ) adalah 0,0926, sedangkan isotherm Freundlich yang menunjukkan bahwa kapasitas adsorpsi maksimum logam Fe sebesar 4,938 mg/g dengan koefisien korelasi $\left(\mathrm{R}^{2}\right)$ adalah 0,2317 (Tabel 7). Selanjutnya untuk kapasitas logam Mn menurut isotherm Langmuir menunjukkan kapasitas adsorpsi maksimum logam Mn sebesar 0,025 mg/g dengan nilai korelasi $\left(\mathrm{R}^{2}\right)$ adalah 0,4057 sedangkan kapasitas adsorpsi maksimum logam Mn berdasarkan isotherm Freundlich sebesar 4,296 mg/g dengan nilai korelasi $\left(\mathrm{R}^{2}\right)$ adalah 0,6397 (Tabel 8). 
Tabel 7. Konstanta Isoterm Langmuir dan Freundlich Logam Fe

\begin{tabular}{|c|c|c|c|}
\hline Isoterm & Sampel & Konstanta & Nilai \\
\hline \multirow{6}{*}{ Langmuir } & \multirow{3}{*}{1} & $\mathrm{R}^{2}$ & 0,001 \\
\hline & & $\mathrm{q}_{\max }$ & 5,831 \\
\hline & & $\mathrm{b}$ & 1 \\
\hline & \multirow{3}{*}{2} & $\mathrm{R}^{2}$ & 0,0926 \\
\hline & & $\mathrm{q}_{\max }$ & 1,401 \\
\hline & & $\mathrm{b}$ & 1 \\
\hline Isoterm & Sampel & Konstanta & Nilai \\
\hline \multirow{6}{*}{ Freundlich } & \multirow{4}{*}{1} & $\mathrm{R}^{2}$ & 0,0002 \\
\hline & & $\mathrm{k}$ & 3,653 \\
\hline & & $\mathrm{n}$ & 30,67 \\
\hline & & $\mathrm{R}^{2}$ & 0,2317 \\
\hline & \multirow[t]{2}{*}{2} & $\mathrm{k}$ & 4,938 \\
\hline & & $\mathrm{n}$ & 3,602 \\
\hline
\end{tabular}

Tabel 8. Konstanta Isoterm Langmuir dan Freundlich Logam Mn

\begin{tabular}{cccc}
\hline Isoterm & Sampel & Kontanta & Nilai \\
\hline \multirow{2}{*}{ Langmuir } & 1 & $\mathrm{R}^{2}$ & 0,4057 \\
& & $\mathrm{qm}$ & 0,025 \\
& 2 & $\mathrm{~b}$ & 0,688 \\
& & $\mathrm{R}^{2}$ & 0,1296 \\
& & $\mathrm{qm}$ & 0,677 \\
Freundlich & $\mathrm{b}$ & 2,826 \\
& & $\mathrm{R}^{2}$ & 0,6397 \\
& $\mathrm{k}$ & 4,296 \\
& $\mathrm{n}$ & 1,160 \\
& 2 & $\mathrm{R}$ & 0,1737 \\
& & $\mathrm{k}$ & 5,58 \\
& & $\mathrm{n}$ & 2,986 \\
\hline
\end{tabular}

Berdasarkan hasil nilai korelasi maka pola adsorpsi pada penelitian ini mengikuti pola isoterm Freundlich yang mengasumsikan bahwa adsorbat teradsorpsi pada permukaan adsorben adalah heterogen multilayer. Pada pola adsorpsi isotherm Freundlich kurva diperoleh dengan mengalurkan $\log \mathrm{C}_{0}$ dengan $\log x / \mathrm{m}$. Kemudian konstanta (k) diperoleh dari intersep dan harga $1 / n$ diperoleh dari kemiringan kurva. Nilai k pada isoterm Freundlich merupakan daya adsorpsi adsorben fly ash terhadap logam Fe yaitu sebesar 4,938 mg/g dan nilai n sebesar 3,602, sedangkan nilai $\mathrm{k}$ menurut isotherm Freundlich pada logam Mn sebesar 4,296 mg/g dan nilai n sebesar 1,160. Nilai n menunjukkan karakteristik adsorpsi. Kesesuaian sangat baik apabila nilainya 2-10, cukup apabila nilainya 1-2 dan buruk apabila nilainya $<1$ (Rasmiah, 2013).

\section{KESIMPULAN}

Dari hasil analisis yang telah diperoleh pada pemanfaatan fly ash sebagai adsorben maka dapat disimpulkan bahwa :

1. Hasil difaktogram XRD pada fly ash sebelum dilakukan percobaan menunjukkan bahwa sebagian besar fly ash batubara mengandung senyawa mineral utama yaitu kuarsa $\left(\mathrm{SiO}_{2}\right)$ dan mullite $\left(\mathrm{Al}_{6} \mathrm{Si}_{2} \mathrm{O}_{13}\right)$. Selain itu, fly ash juga memiliki kandungan mineral karbonat yang berfungsi sebagai senyawa alkali seperti aragonite $\left(\mathrm{CaCO}_{3}\right)$, periclase $(\mathrm{MgO})$ dan thomsonite $\left(\mathrm{NaCa}_{2}\left(\mathrm{Al}_{5} \mathrm{Si}_{5}\right) \mathrm{O}_{20}\right)$ pembentuk suasana basa dalam larutan sehingga fly ash dapat meningkatkan pH AAT. Adanya pori sebagai media adsorpsi logam Fe dan Mn. Hasil uji SEM pada fly ash sebelum dilakukan percobaan memiliki sedikit pori dengan ukuran pori kecil, sedangkan pada hasil uji SEM sesudah percobaan pori-pori yang terbentuk semakin banyak dan ukuran terlihat membesar. Pori yang terbentuk menjadi semakin besar dan banyak yang menandakan terjadinya pertambahan luas permukaan. 
2. Adanya penambahan massa fly ash dan kecepatan pengadukan maka terjadi peningkatan $\mathrm{pH}$ dan penurunan konsentrasi logam Fe dan Mn. Efektifitas massa fly ash terhadap perubahan kadar $\mathrm{pH}$ ditunjukkan pada variasi massa fly ash 12 gram dan kecepatan pengadukan $45 \mathrm{rpm}$ yaitu rata-rata sebesar 63,11\%. Kemudian efektifitas massa fly ash terhadap perubahan konsentrasi logam Fe ditunjukkan pada variasi massa fly ash 5 gram dan kecepatan pengadukan $45 \mathrm{rpm}$ yaitu rata-rata sebesar 85,95\%, sedangkan efektifitas massa fly ash terhadap perubahan konsentrasi logam Mn ditunjukkan pada variasi massa fly ash 12 gram dan kecepatan pengadukan 45 rpm yaitu rata-rata sebesar $81,77 \%$.

3. Berdasarkan hasil analisis data menunjukkan bahwa kapasitas adsorpsi logam Fe dan Mn mengikuti model adsorpsi isotherm Freundlich. Hasil analisis menunjukkan bahwa kapasitas adsorpsi logam Fe lebih besar daripada kapasitas adsorpsi logam Mn yaitu kapasitas adsorpsi logam Fe sebesar 4,938 mg/g, sedangkan kapasitas adsorpsi logam Mn sebesar 4,296 mg/g.

\section{DAFTAR PUSTAKA}

Ahalya, N. T.V. Ramachandra, R.D and Kanamadi. 2003. Biosorption of Heavy Metals. Research Journal of Chemistry and Environment 7 (4), p. 71-79.

Amri, A., Suprapto dan Fahrurozi, M. 2004. Kesetimbangan Adsorpsi Optimal Campuran Biner Cd (II) dan Cr (III) dengan zeolit Alam Terimpregnasi 2 Merkaptobenzotiazol. Jurnal Natur Indonesia 6(2), p.111-117.

Bada, S.O., et. al. 2008. Evaluation and Treatment of Coal Fly Ash for Adsorption Application, Leonardo Electronic Journal of Practices and Technologies, 12, p. 37-48.

Musyoka NM, Petrik LF, Balfour G, Natasha M, Gitari W and Mabovu B. 2009. Removal of Toxic Elements from Brine using Zeolit Na-P1 Made from A South African Coal Fly Ash. Proceedings ISBN Number: 978-0-9802623-5-3. Pretoria South Africa.

Oscik, J. 1982. Adsorption, New York. John Wiley \& Sons. 188p.

Sukandarrumidi. 2008. Batubara dan Gambut. Yogyakarta: Gadjah Mada University Press.

Wahyuni, S. 2010. Adsorpsi Ion Logam Zn (II) Pada Zeolite A yang di Sintesis Dari Abu Dasar Batubara PT. IPMOMI Paiton dengan Metode Batch, Prosiding Tugas Akhir Institut Teknologi Sepuluh November. Surabaya.

Undang-Undang Nomor 4 Tahun 2009, Pertambangan Mineral dan Batubara. Citra Umbara. Bandung-Indonesia

Undang-Undang Nomor 32 Tahun 2009, Perlindungan dan Pengelolaan Lingkungan Hidup. Citra Umbara. BandungIndonesia

Keputusan Menteri Negara Lingkungan Hidup Nomor 113 Tahun 2003, Baku Mutu Air Limbah Bagi Usaha dan atau Kegiatan Pertambangan Batubara. Hal :

Peraturan Gubernur Sumatera Selatan Nomor 18 Tahun 2005, Baku Mutu Limbah Cair (BMLC) Bagi Kegiatan Industri, Hotel, Rumah Sakit, Domestik dan Pertambangan Batubara

Peraturan Pemerintah Nomor 101 Tahun 2014, Pengelolaan Limbah B3. 